\title{
HUKUM DAN PERAN LILIFUK DI TENGAH REZIM PEMERINTAHAN: Analisis Hukum dan Keberlanjutan Kearifan Lokal di Desa Kuanheun, Kabupaten Kupang Barat, Nusa Tenggara Timur
}

\author{
Meezan Ardhanu Asagabaldan \\ Program Magister Sumber Daya Pantai \\ Universitas Diponegoro Semarang
}

\begin{abstract}
The main objective of the management of coastal areas and marine resources is preserving resources and improving the welfare in coastal areas and small islands. The Ecological, social and cultural rights of local communities are the foundation for management of sustainable resource. Lilifuk is one of the local wisdoms in, West Kupang, with the aim is to support the conservation of coastal and marine. The main income of Lilifuk is fish catch such as lada/Beronang (Siganus spp.), Alu-alu/barracuda (Sphyranidae), grouper (Ephinephelus), and Peperek (Leigonathidae). Lilifuk has some beneficial thing for economical, social, and environmental aspects. Local communities that are involved, either directly or indirectly, make a significant contribution in keeping the existence of Lilifuk.
\end{abstract}

Keywords: Lilifuk, Kuanheun village, local wisdom, coastal and marine

\section{Pendahuluan}

Indonesia memiliki garis pantai sepanjang $81.000 \mathrm{~km}$ dengan jumlah pulau kurang lebih 17.508. Hal ini membuat Indonesia dikenal sebagai negara megabiodiversity, yaitu memiliki tingkat keanekaragaman hayati yang sangat tinggi. Selain itu, Indonesia juga memiliki kawasan pesisir yang sangat potensial untuk berbagai opsi pembangunan seperti perikanan, pemukiman, obyek wisata, pelabuhan, dan lain-lain, sehingga meningkatkan terjadinya tekanan ekologis terhadap ekosistem dan sumberdaya pesisir dan laut. Seperti yang dikatakan Kementerian Kelautan dan Perikanan 2014, pada sub-sektor perikanan tangkap misalnya, menunjukkan bahwa stok ikan di beberapa wilayah perairan laut seperti Selat Malaka, Laut Jawa, Pesisir Selatan Sulawesi, Selat Bali, dan Laut Arafura telah mengalami penangkapan berlebih (over fishing). Purwanto (2003) menambahkan bahwa beberapa spesies ikan bahkan dilaporkan telah sulit didapatkan bahkan nyaris hilang dari perairan Indonesia.

Kenyataan seperti ini terjadi akibat pola pengelolaan yang tidak mengindahkan prinsip-prinsip keseimbangan dan nilainilai lestari (sustainable values). Untuk itu, perlu adanya suatu pengelolaan untuk mencapai tujuan-tujuan pengelolaan sumberdaya wilayah pesisir secara terpadu dan berkelanjutan.

Mitchell et. al., (2000), menyebutkan bahwa pengelolaan sumber daya alam merupakan upaya-upaya pelestarian dan perlindungan keanekaragaman biologi pada tingkat genetik, spesies dan ekosistem, serta menjamin kekayaan alam, binatang dan tumbuhan di seluruh kepulauan Indonesia. Sumber daya alam yang lestari dapat menjamin keberlanjutan produksi dan pendapatan masyarakat yang 
pada akhirnya akan berdampak pada peningkatan kesejahteraan.

Fauzi (2004) menambahkan aya alam yang baik akan meningkatkan kesejahteraan umat manusia, dan juga sebaliknya yaitu jika pengelolaan sumber daya alamnya tidak baik, maka akan berdampak buruk bagi umat manusia. Pengelolaan sumber daya alam yang arif dan berkelanjutan diperlukan untuk mengantisipasi peningkatan degradasi lingkungan.

Menjaga kelestarian sumberdaya dan meningkatkan kesejahteraan seluruh masyarakat di wilayah pesisir dan pulaupulau kecil menjadi tujuan utama dan pengelolaan sumberdaya wilayah pesisir dan laut. Berbagai aspek seperti aspek ekologi, sosial dan budaya masyarakat lokal harus diperhatikan dan dipertahankan sebagai landasan pengelolaan sumberdaya yang berkelanjutan. Aspek ekologi dapat diwujudkan dalam fungsi-fungsi ekosistem, sedangkan aspek sosial budaya dapat dilihat dari kearifan lokal dalam suatu daerah. Aspek-aspek tersebut merupakan modal utama untuk mencapai kelestarian sumberdaya dan kesejahteraan masyarakat pesisir.

Keraf (2002) mendefinisikan kearifan lokal adalah semua bentuk pengetahuan, keyakinan, pemahaman atau wawasan serta adat kebiasaan atau etika yang menuntun perilaku manusia dalam kehidupan di dalam komunitas ekologis. Kearifan tradisional ini bukan hanya pada pengetahuan atau pemahaman masyarakat adat tentang manusia dan bagaimana relasi yang baik, melainkan juga tentang pengetahuan, pemahaman dan adat kebiasaan tentang manusia, alam dan bagaimana relasi di antara semua penghuni komunitas ekologi. Seluruh kearifan tradisional ini merupakan warisan dari satu generasi ke generasi lain yang telah diajarkan secara turun-menurun sehingga membentuk pola perilaku manusia seharihari baik terhadap sesama manusia maupun terhadap alam dan yang gaib.

Berbagai bentuk kearifan lokal dan kelompok masyarakat adat di Indonesia mempraktikkan cara tradisional untuk mengelola sumberdaya pesisir, seperti Awig-awig di Nusa Tenggara Barat ataupun Sasi di Papua dan Maluku. Keikutsertaan masyarakat lokal dan kearifan lokal diakui secara hukum dalam peraturan perundang-undangan Indonesia. Hal ini seiring dengan adanya perubahan rezim pemerintahan dari sentralisasi ke desentralisasi mengubah sistem hukum Indonesia, termasuk di bidang kelautan dan perikanan dimana kewenangan pengelolaan wilayah pesisir dan laut dapat melibatkan masyarakat lokal melalui kemitraan dan mendorong masyarakat untuk berpartisipasi dalam pengelolaan wilayah pesisir dan laut.

Laut Sawu, Nusa Tenggara Timur telah ditetapkan oleh pemerintah Republik menjadi Kawasan Konservasi Perairan Nasional Taman Nasional Perairan (TNP) melalui Keputusan Menteri Kelautan dan Perikanan Republik Indonesia No. 5 tahun 2014.

Terdapat sekitar 20 kearifan lokal yang tumbuh dan berkembang di masyarakat desa pesisir di TNP Laut Sawu Ada sekitar 20 kearifan) di TNP Laut Sawu. Salah satu contohnya adalah Lilifuk di Kabupaten Kupang tepatnya di Desa Kuanheun, Kecamatan Kupang Barat, Nusa Tenggara Timur

Lilifuk merupakan salah satu kearifan lokal yang sudah ada secara turun-temurun dilakukan dengan tujuan untuk mendukung 
konservasi pesisir dan laut yang terdiri dari penangkapan ikan dengan alat dan cara ramah lingkungan. Kearifan lokal pengelolaan Lilifuk telah membentuk suatu hukum adat yang wajib dipatuhi oleh masyarakat pesisir, khususnya di Desa Kuanheun. Hukum-hukum adat yang telah dibuat oleh Lilifuk tidak lepas hubungannya dengan peraturan-peraturan pemerintah khususnya Kementerian Kelautan dan Perikanan (KKP). Kebijakan yang telah dibuat oleh pemerintah KKP dalam mengelola sumber daya pesisir, baik dari segi konservasi, ekologi, maupun masyarakat disana, sehingga terjadi hubungan antara hukum adat yang dibentuk oleh Lilifuk dengan peraturanperaturan pemerintah yang berlaku.

Tujuan dari penulisan makalah ini adalah membahas bagaimana peran dan pelaksanaan kearifan lokal Lilifuk di Desa Kuanheun, Laut Sawu, Kupang dalam upaya menjaga kelestarian dan ketersediaan sumber daya laut bagi kehidupan masyarakat, khususnya penikanan. Selain itu juga untuk mengetahui bagaimana peran dan fungsi hukum adat Lilifuk di masyarakat pesisir Laut Sawu seiring dengan rezim peraturan pemerintahan KKP dan pemerintah lainnya.

\section{Pembahasan}

\subsection{Gambaran Umum Desa Kuanheun,} Laut Sawu Kabupaten Kupang Barat

Desa Kuanheun terletak di bagian Barat Kecamatan Kupang Barat Kabupaten Kupang Propinsi Nusa Tenggara Timur. Desa Kuanheun memiliki batas-batas daerah sebagai berikut; Utara: Desa Bolok Selatan: Desa Oematnunu; Barat: Selat Semau/Laut Sawu; Timur: Kelurahan Batakte (Gambar 1). Luas wilayah Desa Kuanheun secara keseluruhan adalah 2.146 Ha, dimana luas tersebut dibagi menjadi delapan fungsi yaitu untuk pemukiman seluas $658 \mathrm{Ha}$, persawahan

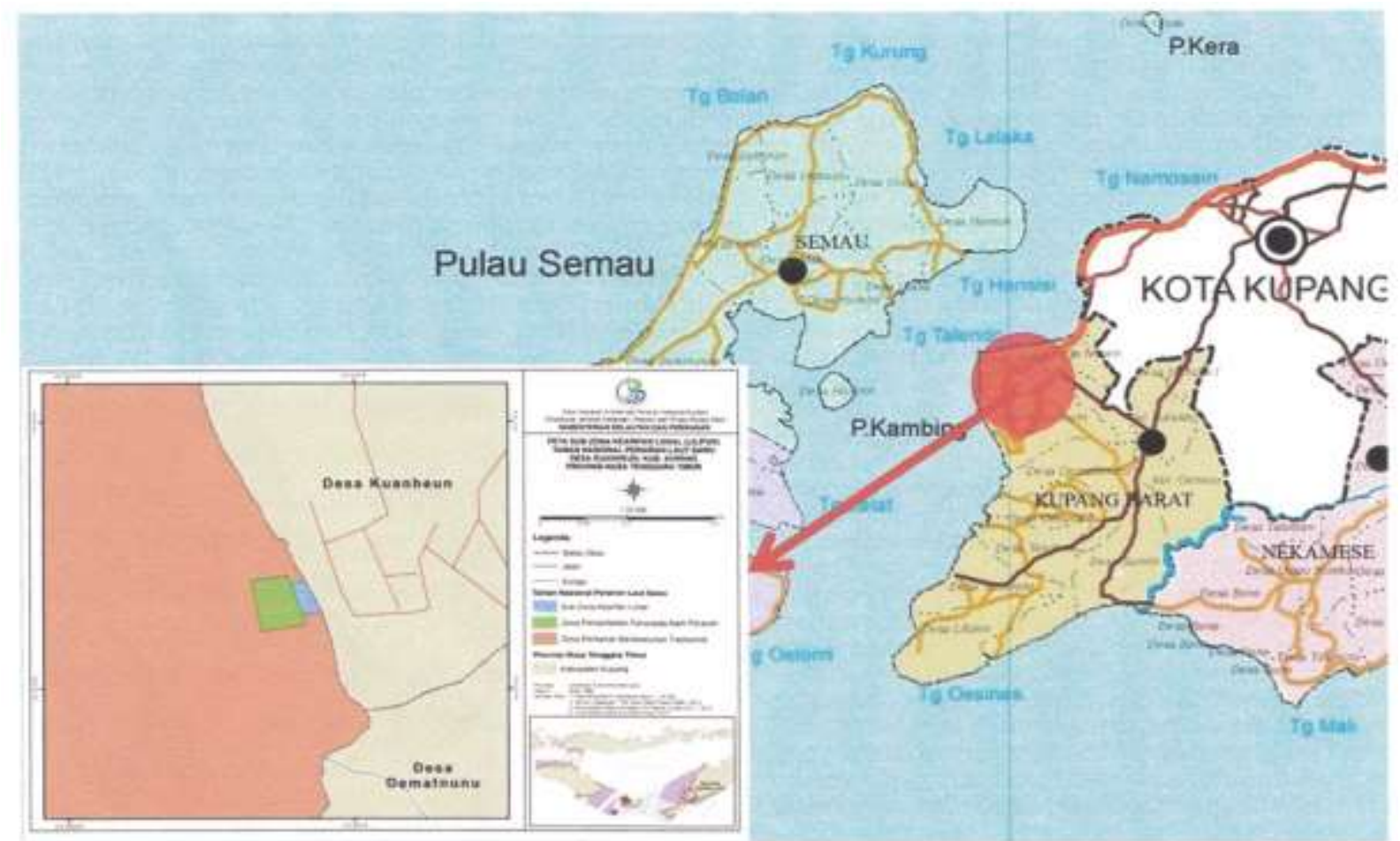


Gambar 1. Peta Desa Kuanheun, Kabupaten Kupang Barat, Kupang. Nusa Tenggara Timur (Sumber: www.google.com)

$280 \mathrm{Ha}$, perkebunan (p)128 Ha, kuburan $40 \mathrm{Ha}$, pekarangan $740 \mathrm{Ha}$, taman $100 \mathrm{Ha}$, perkantoran $25 \mathrm{Ha}$, dan $175 \mathrm{Ha}$ untuk prasarana umum lainnya.

Desa Kuanheun secara umum merupakan dataran rendah dengan tingkat kemiringan 0.10. Desa Kuanheun terletak di pesisir pantai yang memiliki iklim yang tidak jauh berbeda dengan daerah-daerah lainnya di Provinsi Nusa Tenggara Timur yaitu beriklim tropis, suhu rata-rata $31.5^{\circ} \mathrm{C}$ yang memiliki jumlah bulan hujan selama tiga bulan dengan curah hujan $1000 \mathrm{~mm}$. Jumlah penduduk Desa Kuanheun adalah 1.506 jiwa dengan jumlah laki-laki berjumlah 718 jiwa dan perempuan 788 jiwa. Pekerjaan penduduk Desa Kuanheun yang paling dominan adalah petani.

Sumberdaya pertanian di desa Kuanheun ini sangat tergantung dengan kondisi alam dan musim. Lahan pertanian yang terbatas membuat para penduduk Desa Kuanheun melakukan kerja sampingan seperti berkebun, dan mencari ikan (nelayan). Komoditas pertanianny di Desa Kuanheun meliputi; jagung, kacang tanah, ubi kayu, tomat, mangga, pisang, semangka, dan pepaya.

Pada sektor perikanan dan kelautan, perairan laut desa Kuanheun (diganti desa) merupakan bagian dari Taman Nasional Perairan (TNP) Laut Sawu yang memiliki potensi perikanan yang cukup baik dan sudah memiliki pengelolaan secara tradisional melalui kearifan lokal Lilifuk. Sehubungan adanya aturan dan hukum adat Lilifuk, masyarakat khususnya para nelayan tidak dapat menangkap ikan secana bebas di area yang telah disepakati sebelumnya. Ada batasan-batasan yang telah dibuat, sehingga budidaya rumput laut menjadi pilihan bagi para nelayan untuk menjadi mata pencahariannya. Budidaya rumput laut tersebut juga tidak terlepas dari setelah mendapat izin dari masyarakat setempat.

\subsection{Potensi Perikanan dan Kelautan Desa Kuanheun Kabupaten Kupang Barat}

Desa Kuanheun berbatasan dengan Laut Sawu yang memliki sumber daya perikanan dan laut yang cukup potensial antara lain seperti, berbagai jenis ikan laut, padang lamun, hutan mangrove, terumbu karang dan juga rumput laut. Sumber daya tersebut dimanfaatkan sebagai bahan makanan dan sisanya dijual untuk mendapatkan uang. Lokasi desa yang strategis ini membuat masyarakat melakukan budidaya rumput laut sekaligus menangkap ikan pelagis dan ikan karang. Oleh karena itu, sebagian besar masyarakat setempat bermata pencaharian sebagai nelayan.

Melimpahnya ikan karang di sekitan Desa Kuenheun dikarenakan masih banyaknya terumbu karang di pesisir pantai desa. Jenis karang yang ada di pesisir desa terdiri atas karang lunak, karang bercabang, dan karang otak. Selain itu, masih dapat ditemukan beberapa padang lamun Enhalus Acaroides dan Thalisia Hempricii yang menjadi habitat ikan-ikan kanang seperti ikan lada/Beronang (Siganus Spp.), Alualu/banakuda (Sphyranidae), Kerapu (Ephinephelus Spp.), dan Peperek (Leigonathidae) yang merupakan ikan yang sering dijumpai di daerah setempat)/ (Gambar 2.)

\subsection{Kearifan lokal Lilifuk di Desa Kuenheun}

Lilifuk merupakan pengelolaan sumber daya laut berbasis kearifan lokal oleh masyarakat Kupang. Kearifan lokal yang dikenal dengan Lilifuk ini 
mendukung konservasi pesisir dan laut yang terdiri dari penangkapan ikan dengan alat dan cara ramah lingkungan. Lilifuk adalah suatu kolam besar yang dipenuhi dengan padang lamun yang kaya akan ikan lada (banonang) dan ikan dusung yang berada di tepi laut. Apabila air laut surut, kolam besar ini akan tampak dengan kedalaman maksimum 5 meter dengan luas $20.000 \mathrm{~m}^{2}$, sehingga ikan banyak yang terperangkap di dalamnya

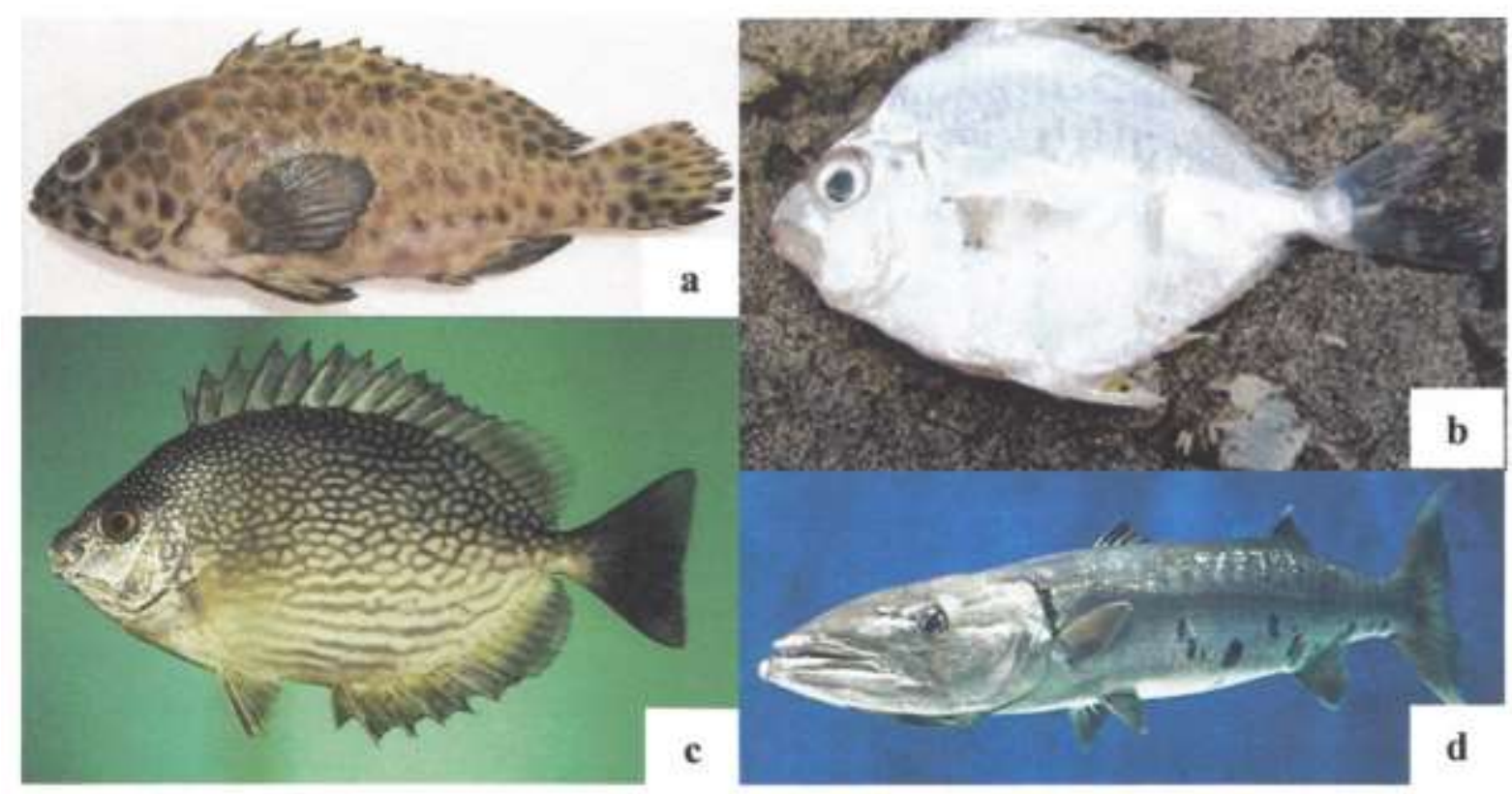

Gambar 2. Komoditas ikan lokal yang ada di kolam Lilifuk Desa Kuanheun; a) Kerapu; b) Petek/Peperek; c) Lada / Beronang; d) Alu-Alu / Barakuda (sumber www.google.com)

Oleh karena itu masyarakat Kupang, khususnya Desa Kuenheun kemudian mengelola sumber daya ini untuk ditutup dari aktivitas penangkapan ikan sehari-hari dan dibuka untuk sekali atau dua kali dalam setahun sesuai dengan kesepakatan untuk dapat dimanfaatkan. Lilifuk tersebut merupakan hak milik dari suatu suku tertentu dengan pengelolaannya dilindungi oleh hukum adat.

Terdapat tiga jenis Lilifuk di daerah Kupang yaitu; Lilifuk Baimusu dan Lilifuk Gatal di Desa Bolok, serta Lilifuk Baineo di Desa Kuanheun. Batas-batas wilayah Lilifuk yang ditutup sebagai daerah konservasi yaitu sejajar dengan garis pantai dengan luas: a) Lilifuk Gatal: $200 \mathrm{x}$ 100 m, b) Lilifuk Gatal: 370 x 30 m, dan c)
Lilifuk Baineo: 100 x 50 m. Batas-batas wilayah tersebut diberi tanda dengan menggunakan batu. Akan tetapi, karena batu-batu tersebut sering dibongkar pada saat dibuka, maka batas tersebut diganti dengan menggunakan kayu.

Lilifuk di Desa Kuenheun berada di dalam penguasaan suku Baineo penduduk kampung RT 14 Taunesi Desa Kuanheun. Lilifuk atau dengan kata lain menurut istilah lokal Masyarakat Desa Kuanheun disebut Nifu adalah; daerah cekung pada permukaan dasar perairan pantai yang menyebabkan adanya genangan air laut pada saat surut tertinggi. Kondisi tergenangnya air laut pada saat surut ini menyerupai Kolam besar di Laut, sehingga masyarakat setempat menyebutnya dengan 


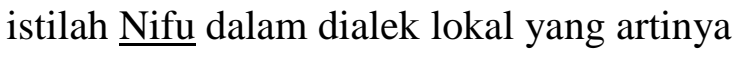
kolam.

Sejarah awal mula adanya Lilifuk/Nifu Loles diprakarsai suku/klan Baineo. Terbentukya Lilifuk ini sejak ratusan tahun yang lalu, menurut seorang narasumber yang juga salah seorang anak Suku/Klan Baineo menuturkan bahwa, hak penuh suku/klan Baineo terhadap Lilifuk/Nifu Loles diawali dengan Perang antara suku/klan Baineo (Desa Kuenheun) dan suku/klan Lai (Desa Bolok) memperebutkan tiga gugusan lokasi terhitung dan lokasi perairan pantai (Tinmau). Nam Tinmau nama sebuah kolam yang sederetan dengan Lilifuk/Nifu Loles, memiliki kedalaman lebih dari 15 meter, berbentuk lingkaran yang berdiameter \pm 500 meter dan dasar kolam tersebut terdiri dari populasi terumbu karang yang merupakan tempat berkembangbiaknya ikan. Dalam peperangan tersebut terdengar kalimatkalimat umpatan. Sebuah kata umpatan dalam bahasa Dawan yang ditujukan suku/Klan Baineo kepada Suku/Klan Laikopan yang berbunyi "Ho Loel Man" yang artinya "Kau punya Otak", sehingga sejak saat itu tempat ataupun pantai dimana terjadi peperangan itu dinamakan Pantai Loles (terjemahan dan kata " $\mathrm{Ho}$ Loel Man"). Suku Laikopan mengalami kekalahan dan melarikan diri ke Pulau Semau. Sementara itu suku Baineo berhak memiliki kearifan lokal dalam perairan tersebut (Hidayat, 2014).

Pengelolaan sumberdaya pesisir dan laut sudah terbukti dapat menjamin keberlangsungan sumberdaya tersebut. Hal ini perlu diperhatikan untuk memperkuat ataupun mengembalikan budaya yang sudah tidak dilaksanakan. Upaya untuk mengembalikan kepercayaan masyarakat terhadap kearifan lokal sumberdaya pesisir dan laut perlu dilakukan, yaitu memperkuat kelembagaan masyarakat lokal, peningkatan apresiasi budaya lokal dan menggali substansi kearifan lokal yang mulai memudar. TNP Laut Sawu memiliki banyak kearifan lokal yang mendukung pengelolaan kawasan konservasi, seperti budaya Lilifuk di Kabupaten kupang.

\subsection{Hukum Adat Lilifuk di Desa Kuenhuen}

Lilifuk di desa Kuenheun telah dikuasai oleh Suku Baineo, sehingga pengelolaannya pun diatur berdasarkan kesepakatan adat suku Baineo. Ada beberapa hukum adat Lilifuk di desa Kuenheun yang harus ditaati oleh masyarakat, yaitu sebagai berikut:

1. Bahwa setiap orang dilarang masuk dan mengambil ikan di dalam Lilifuk sampai dengan batas waktu yang ditentukan.

2. Masa panen Lilifuk dilaksanakan satu kali dalam setahun, kebiasaan setahun sekali ini dikenal dengan istilah TUT NIFU, namun yang sekarang menjadi wacana adalah panen Lilifuk dilakukan dua tahun sekali yaitu pada bulan Juni dan bulan Desember.

3. Pada saat panen Lilifuk diharuskan memberi undangan kepada desa-desa tetangga.

4. Upeti/kontribusi bagi suku Baineo selaku pemilik Lilifuk pada saat panen adalah beberapa ekor ikan yang diambil dari hasil tangkapan setiap undangan yang datang dalam istilah adatnya adalah "Tanaib Ika" artinya seikat ikan.

Hukum adat tersebut disepakati dan ditetapkan dalam sebuah upacara ritual 
yang dikenal dengan istilah adat Tasaeb Talas yang artinya mendirikan ramburambu. Beberapa sanksi yang dijatuhkan kepada oknum yang melanggar antara lain, dikenakan sanksi barupa satu ekor hewan (sapi, babi dan kambing) dan bagi pelaku yang melakukan pencurian ikan di kolam Lilifuk akan dikenakan sanksi adat berupa satu ekor babi dengan berat $100 \mathrm{~kg}$. Pelaku yang menggunakan alat tangkap pukat garu yang dapat mengakibatkan rusaknya Lilifuk akan dikenakan sanksi adat berupa uang Rp. 1.000.000,-.

\subsection{Keikutsertaan Lilifuk terhadap Pengelolaan Sumber Daya Perikanan}

Terdapat lima elemen masyarakat yang berperan dalam pengelolaan Lilifuk, yaitu tokoh agama, tokoh adat, pemerintah desa, masyarakat, dan orang luar desa. Lima komponen masyarakat tersebut memiliki fungsi yang sesuai dengan perannya. Tokoh adat memiliki peran sebagai penjaga sumber daya perikanan seperti karang, lamun, habitat, ekosistem, khususnya ikan-ikan yang ada di dalam Lilifuk dan membantu pemerintah desa dalam pengawasan terhadap pencurian ikan (illegal fishing).

Tokoh agama dan pemerintah desa berfungsi sebagai pengambil kebijakan, pertimbangan serta pemberian dukungan di dalam penerapan aturan yang sudah dibuat. Pemerintah desa juga berperan sebagai pemberi informasi kepada masyarakat luas ketika Lilifuk dibuka. Sementara itu, Masyarakat disini memiliki peran penting yaitu menjaga kolam Lilifuk dan mentaati peraturan yang sudah dibuat. Penangkapan ikan hanya dilakukan pada saat dibukanya Lilifuk. Penangkapan ikan tersebut biasanya dilakukan dalam dua hari tergantung dari keputusan pemilik Lilifuk. Pembukaan Lilifuk biasanya dimulai dengan pesta adat dan ritual agama sebelum dilakukannya panen ikan di wilayah tersebut.

Upaya melegalisasi nilai-nilai tradisional dalam pemanfaatan dan pelestarian sumberdaya pesisir telah dilakukan oleh lembaga pemerintahan desa melalui Peraturan Desa Nomor 1 tahun 2012 tentang Perlindungan Sumberdaya Laut di Wilayah Lilifuk. Peraturan merupakan bentuk antusias dari masyarakat dan beberapa elemen di Desa Keunheun untuk selalu menjaga kearifan dalam pelestarian sumberdaya pesisir dan laut.

Dalam Peraturan desa ini, terdapat tujuh larangan yang disertai dengan 12 sanksi bagi setiap pelanggar. Larangan dalam peraturan desa ini antara lain setiap orang dilarang menggunakan alat tangkap yang merusak biota laut, dilarang menangkap ikan di zona kearifan Lilifuk sebelum waktunya, dilarang merusak, mengambil penyu dan terumbu karang, dilarang melakukan pencurian, termasuk pasir dan batu laut, dilarang dilakukan pencemaran laut, serta dilarang merusak tempat pengeringan garam.

Selain sanksi adat di atas, ada beberapa sanksi yang telah dibuat oleh Perdes ini, di antaranya setiap orang yang menggunakan pukat garu dalam Lilifuk dikenai sanksi adat berupa denda Rp 1 juta dan beras $100 \mathrm{~kg}$, setiap orang yang menggunakan sorok lingkar dikenakan sanksi Rp 500.000. Juga ada sanksi bagi setiap orang yang melakukan penangkapan ikan dengan bubu, menangkap penyu, penggunaan bom dan racun ikan, merusak terumbu, pencemaran perairan dan pengrusakan tempat pengeringan garam. Selain mengatur dalam kegiatan penangkapan, Perdes ini juga mengatur 
pengelolaan wilayah pesisir dalam bidang lain seperti budidaya, pariwisata, dan pertambangan pasir laut.

Lilifuk merupakan suatu bentuk hak ulayat laut dimana hak penguasaan masyarakat atas tanah, air sungai, pantai, tumbuh-tumbuhan liar, satwa liar di dalam lingkungan guna kepentingan masyarakat sendiri dan anggota-anggotanya serta orang luar (Yulianto, 2008). Hal ini diperkuat oleh UU No. 22 Tahun 1999 yang merupakan kekuatan yang mengakui eksistensi institusi yang ada di beberapa daerah dalam mengelola sumber daya ikan.

Keikutsertaan masyarakat dan kearifan diakui secara dalam peraturan perundang-undangan Indonesia. Hal ini diatur pada Peraturan Menteri KKP No. 40/ PERMEN-KP/2014 tentang peran serta dan pemberdayaan masyarakat dalam pengelolaan wilayah pesisir dan pulaupulau kecil. Selain itu juga tercermin dalam kebijakan tentang perlindungan SDA dan keterlibatan masyarakat, seperti UU No. 31 tahun 2004 tentang Perikanan Jo UU No. 45 tahun 2009, UU No. 27 tahun 2007 tentang Pengelolan Wilayah Pesisir dan Pulau-Pulau Kecil Jo UU No. 01 tahun 2014, dan PP 60 Tahun 2007 tentang Konservasi Sumberdaya Ikan.

Berbagai upaya pengelolaan kawasan pesisir dan laut yang berkelanjutan adalah dengan melakukan upaya konservasi yang berbasis masyarakat, partisipatif dan kolaboratif. Lilifuk merupakan salah satu pengelolaan sumber Community Based Management (CBM) dimana CBM merupakan suatu proses pemberian wewenang, tanggung jawab dan kesempatan kepada masyarakat untuk mengelola sumber daya kelautan dan perikanan sendiri dengan memperhatikan kebutuhan, keinginan, tujuan dan aspirasinya (Nikijuluw, 2002).

\subsection{Keberlanjutan Lilifuk di Desa Kuanheun}

Kearifan lokal Lilifuk di Desa Kuanheun memiliki manfaat yang baik bagi masyarakat, sehingga perlu dijaga keberlanjutan dari Lilifuk ini. Manfaat yang bisa didapat adalah manfaat secara ekonomi, sosial maupun lingkungan. Manfaat ekonomi yang dirasakan oleh masyarakat adalah menambah penghasilan dan penangkapan ikan pada saat buka Lilifuk. Sementara itu manfaat sosial yang diterima adalah meningkatkan hubungan atau interaksi sosial antara satu rumah tangga dengan rumah tangga lainnya serta menjaga hubungan sosial dengan tetangga sekitarnya yang ikut pada waktu buka Lilifuk, bahkan dengan masyarakat di luar desa tersebut. Manfaat sosial lainnya Lilifuk menjadi suatu hiburan yang ingin melihat acara buka Lilifuk tersebut. Selain itu, Lilifuk menjaga tradisi setempat karena Lilifuk merupakan warisan orang tua dan juga menjaga budaya daerah setempat karena pada saat dibukanya dilakukan pesta adat yang menampilkan acara-acara seni setempat (Yulisti, 2009).

Lilifuk ini juga memberikan manfaat bagi lingkungan ekologinya yaitu terjaganya ikan karena daerah tersebut ditutup selama setahun. Ikan tersebut akan tumbuh besar dan berkembang di daerah tersebut sehingga keberlanjutan sumber daya ikan terjaga, disamping sumber daya perikanan lainnya. Dengan adanya Lilifuk, masyarakat akan menjaga lingkungannya secara baik dengan tidak membuang sampah sembarangan di laut dan pantai dan tidak menggunakan alat tangkap yang merusak sumber daya. 
Masyarakat di Desa Kuanheun menyadari pentingnya keberadaan Lilifuk dengan segala manfaatnya yang langsung dirasakan oleh mereka. Keberlanjutan Lilifuk akan selalu dijaga oleh masyarakat, karena dengan merusaknya berarti secara tidak langsung masyarakat akan mendapatkan dampaknya juga. Oleh karena itu masyarakat berusaha untuk menjaga kawasan perairan di sekitar Lilifuk baik dan dalam lingkungan maupun dan luar lingkungannya. Namun begitu, beberapa hal yang tidak dapat dihindari oleh masyarakat yang dapat mengancam sumber daya perainan di sekitar Lilifuk dan pengelolaannya baik pengaruh dari luar maupun dari dalam, yaitu sebagai berikut:

1. Lahan perairan semakin sempit karena adanya budidaya rumput laut

2. Pencemaran limbah cucian dari perusahaan budidaya tersebut

3. Perairan semakin kotor dan tercemar dari beberapa kegiatan lainnya. Permasalahan utama adalah minyak dan pembuangan sampah sembarangan

4. Ikan-ikan di perairan berkurang dan kerusakan terumbu karang

Selain manfaat dan kendala dalam Lilifuk, mekanisme pengambilan keputusan dalam Lilifuk juga penting dalam keberlanjutan Lilifuk. Hal ini akan mempengaruhi masyarakat untuk mengambil sikap apakah akan mendukung keberlanjutan atau sebaliknya menghilangkan Lilifuk. Lilifuk memiliki manfaat yang cukup besar bagi masyarakat, maka perlu dipikirkan bagaimana menjaga keberlanjutan Lilifuk.

Faktor-faktor utama yang menjadi prioritas pada Lilifuk ini adalah menjaga dan melindungi serta memperbaiki kelestarian lingkungan, menerapkan aturan dan sanksi hukum, serta menggunakan alat tangkap ramah lingkungan, adanya dukungan dan pengawasan pemerintah. Dalam rangka pencapaian keberlanjutan Lilifuk tersebut, beberapa hal harus dilakukan bersama-sama baik oleh masyarakat, pemerintah maupun tokohtokoh masyarakat seperti tetua adat dan tokoh agama. Banyaknya pencurian ikan dikawasan Lilifuk menyebabkan masyarakat berpendapat pentingnya aspek tersebut untuk lebih diperhatikan.

\section{Ssimpulan}

Kearifan lokal seperti Lilifuk ini, memiliki nilai-nilai ekologi dan prinsip pelestarian lingkungan pesisir yang merupakan bentuk kepedulian masyarakat. Untuk itu, perlu dipertahankan dalam rangka mendukung pengelolaan sumberdaya pesisir dan laut secara berkelanjutan. Kearifan lokal Lilifuk di Desa Kuenheun Kabupaten Kupang merupakan salah satu bentuk revitaliasi kearifan lokal di Laut Sawu.

Penerapan Peraturan Desa Kuenheum tentang perlindungan sumberdaya laut di wilayah Lilifuk yang mengacu pada hukum adat pada jaman dahulu sebagai bentuk upaya pelestarian kearifan lokal ini. Peraturan ini dapat bermanfaat bagi upaya perlindungan, pelestarian dan pemanfaatan sumberdaya pesisir sehingga dapat menjaga ketersediaan sumber daya laut bagi kehidupan masyarakat, khususnya daerah pesisir di Desa Kuenhuen, Laut Sawu.

Lilifuk dapat bermanfaat secara berkelanjutan bagi masyarakat baik secara ekonomi, sosial maupun lingkungannya namun harus memperhatikan aspek-aspek pengelolaan yang berkelanjutan. Masyarakat lokal yang terlibat, baik langsung maupun tidak langsung, dapat berperan serta memberikan kontribusi yang nyata dalam menjaga keberadaan Lilifuk. 
Pada akhirnya perlu adanya dukungan dan keterlibatan dari pemerintah pusat (KKP) maupun kelembagaan lokal lembaga adat dan pemerintahan desa agar pemanfaatan dan pelestarian sumberdaya pesisir di Desa Kuenhuen, Kupang dapat berlangsung secara efektif dan optimal.

\section{Daftar Pustaka}

Fauzi, A. 2004. Ekonomi Sumber Daya Alam dan Lingkungan: Teori dan Aplikasi. Jakarta: PT. Gramedia Pustaka Utama. 259 hal.

Hidayat, R. dan Guntur Wibowo. 2014. "Kearifan Lokal "Lilifuk" mendukung Pengelolaan Taman Nasional Perairan Laut Sawu Berbasis Masyarakat." Penelitian. Lembaga Laporan Penelitian USU.

Keputusan Menteri Kelautan dan Perikanan Nomor 6 tahun 2014 tentang Rencana Pengelolaan dan Zonasi TNP Laut Sawu 2014 - 2034.

Keraf, A. Sony. 2002. Etika Lingkungan. (Etika Lingkungan). Jakarta: Penerbit Buku Kompas.

Mitchell, B., B. Setiawan \& H.R. Dwita. 2000. Pengelolaan Sumber daya dan Lingkungan. Yogyakarta: Gajah Mada University Press.

Nikijuluw, V.P.H. 2002. Rezim Pengelolaan Sumber Daya Penikanan. Jakarta: Pustaka Cidesindo.

Purwanto. 2003. Pengelolaan Sumberdaya Perikanan, Direktorat Jendral Perikanan Tangkap, Jakarta: Departemen Kelautan dan Perikanan.

Yayasan Pengembangan Pesisir dan Laut, 2010. Pemetaan Partisipatif Taman Nasional Perairan Laut Sawu. Laporan untuk The Nature Conservancy. Kupang, Indonesia.

Yulianto, G. 2008. Kajian Kelembagaan Hak Ulayat Laut di Desa-Desa Pesisir Teluk Bintuni. Buletin Ekonomi Perikanan Volume VIII (2): 82-89.

Yulisti M, Kurniasari N, Yuliaty C. 2009. "Analisis keberlanjutan Lilifuk Tinjauan perepsi masyarakat lokal. Jurnal Sosial Ekonomi dan Perikanan Volume 9 (20 4). 